Bangladesh Journal of Bioethics 2010; 1(3):43-46

\title{
INTELLECTUAL PROPERTY RIGHTS AND DEVELOPING COUNTRIES
}

\section{Arif Hossain ${ }^{1}$ Shamima Parvin Lasker ${ }^{2}$}

1. Vice President, Bangladesh Bioethics Society, Bangladesh.

Email: ykhsmh@yahoo.com

2. Professor \& Head, Department of Anatomy, City Dental College, Dhaka, Bangladesh. Email: splasker04@yahoo.com

\begin{abstract}
Knowledge is the multidimensional outcome of human intellect. Intellectual Property Rights system (IPRs) is considered from economic and legal aspect as the ownership rights for the excessive use of innovation and creative work. IPRs are measured to encourage innovation, promote investment in S\&T and make the technologies for public benefit. But history shows that from the time of industrial revolution in Europe and during twentieth century in the North America and Japan, IPRs contribute to the S\&T driven economic growth. Therefore, there is a fair and consistent relationship between strength of IPRs and per capital income. A recent study of World Bank suggested that the major beneficiaries of IPRs in terms of enhanced value of patents are the developed countries with USA along made an annual gain of US \$ 20 billion while developing country face an annual loss of 7.5 billion on royalties and license fees. Moreover, for the developing county, while indigenous technological capability is a significant determinant to economic growth and poverty reduction, no exact relationship has been established between the IPRs and economic growth. Developed countries and business corporations who are benefited directly from IPRs regime insist on implementation of strong IPRs for all countries. Need for strong IPRs for developing and least developed countries are discussed. Strong IPRs for all countries whether it leads to transfer of wealth from poor countries to rich countries to further widen the economic divide is a major ethical concern.
\end{abstract}

Introduction: Knowledge is the multidimensional outcome of human intellect. Intellectual Property Rights (IPRs) is the legal protection over scientific and technological knowledge through the patents, copy writes and other novel legal means. IPRs are considered to encourage innovation, promote investment in science and technology (S\&T) and make the technologies work for public benefit.

In economic growth and development the power of the knowledge has come into sharp focus since the days of industrial revolution and more recently with the advance in science $\&$ technology. IPRs usually have seen from economic and legal perspective as the ownership rights for the excessive use of innovation and creative work. Science and technology activity is the engine to economic development in the contemporary world. According to the classical theory on S\&T and IPRs, S\&T is the machine and IPRS is the fuel. History shows that from the time of industrial revolution in Europe and during twentieth century in the North America and Japan shows that IPRs contribute to the science and research (S\&R) driven economic growth. 
However, in case of developing counties indigenous technological capability is a critical determinant to economic growth and poverty reduction, but no precise relationship has been established between the IPRs and economic growth.

Conflicts about IPRS: The present conflict of IPRs is sharpened by the increase presence of private sector in S\&T and its rush for establishing exclusive rigid, legal ownership on the knowledge intensive modern technological service in order to leverage such ownership for exclusive trade and other strategic advantages.

Developed countries and business corporations who may benefited directly from IPRs regime insist on strong IPRs for all counties in the globalization process under TRIPs (Trade Related Aspect of Intellectual Property Rights), established in 1994 that WTO members countries have to abide by within specific deadlines.

As many of the IP protected technologies are owned by the private sector in the developed countries, they are the major beneficiaries of TRIPs mediated strong patent regime. When most of the innovation (97\%) in the hand of developed countries. Only 3\% of global patents are owned by developing countries Of the 93\% patents on biotechnology in USA, European Union and Japan and rest 7\% from other countries.

Hence the criteria for measuring the social benefit of IPRS are deferent.

A recent world bank analysis suggests that the major beneficiary of TRIPs on term of enhanced value of patents are the developed countries with USA alone expected to make an annual gain of US\$ 19 billion while developing countries face loss of US\$ 7.5 billion on royalties and license fees.

Strong IPRs and developing Countries: Strong and uniform IPRS regime prescribe under the "one size fits all "principal may essentially hinder development in developing countries. This particulate form of IPRs would exploit the developing countries by exorbitant price being levied for licensing and consequent social losses in economic welfare. Therefore the major ethical issues are that strong IPRs led to transfer of wealth from the poor to the rich which widen the economic divide.

Developing countries participate in global intellectual property systems as 'second comers' in a world that has been shaped by the 'first comers'. They are now being urged to adopt a complex set of rules more suited to advanced economy is a major ethical concern. Developing countries are the late comer in the world economy are also disadvantaged bearing disappropriate share of cost with respect to the benefit is an another concern.

Strong IPRs may facilitate technology transfer under licensing it may not promote investment and growth of indigenous S\&T. It rather chokes the domestic R\&D in developing counties. The deficiency of the human and technical capacity to innovate also irrelevant to strong IPRs in stimulating R\&D in many developing country. 
Protection is not necessarily better. Developing countries should not be encouraged or coerced into adopting stronger IP rights without regards to the impact this has on their development and poor people. They should be allowed to adopt appropriate rights regimes, not necessarily the most protective ones."

IPRs, as a whole is less advantageous for developing than for developed countries in many areas of importance to development, such as health, agriculture, education and information technologies. The system increases the costs of access to many products and technologies that developing countries need.

Weak IP and developing countries: Before implementation of TRIPS, in 1995 it was the strength of IPRs which determines the growth of the indigenous S\&T and economy in the developing countries. Without strong IP regime many countries has developed economy. For example without strong IP protections as well as no protection for pharmaceutical products, south Korea achieved economic growth which led to their economic transformation from developing to developed country. Similarly Switzerland, Holland and Japan benefited from their ability to technology catch up without patent law for many years after founding the Paris convention. Japan introduced the product patent only in 1976. In India a weak IP protection contributed to rapid and significant growth of India's pharmaceutical industries particularly a low cost generic medicine and intermediates. Weak IPRs existed in some East Asian and Latin American countries also encourage FDI (Fireign Direct investment).

Indications are that the economic development in developing counties are not essentially require strong IP protection and most of these countries tend to apply a less stringent IPRs regime until their per capital income is by and large above the UDS\$ 8000.

Conclusion: The right to human and economic development, the right of access to food, medical care, health and well being and right to social security shall stand denied or limited in a global IPRs regime under TRIPs and it violates the Universal Declaration of Human Rights (UDTH) as well. There is also need for more intense debate and discussion on the ethical aspect of the TRIPs.

\section{References:}

1. Ethics of information Communication technology in Ethics in Asia pacific, UNESCO Bankok, 2004.

2. WHO 2002. Genomics and WorldHealth organization. www3.who.int/whois/genomics/genomics_report.cfm 
3. Kumar n 2002 Intellectual property Rights, Technology and Economic development; Experience in Asian countries. Commission on Intellectual Property Rights background paper. London.

4. Maskis K 2000. Intellectual property Rights and global economy. Institute for international economic, Washington DC.

5. World Bank 2002. Global Economic prospects and the developing countries 2002. www.worldbank.org/prospactys/gep2002

6. World Bank 2002. World development indicators 2001 www.worldbank.org/data/wdi2001/

7. Roderick RL 1995. The libertarian case against intellectual Property Rights. Liberal National foundation. http://www.libertariannation.org/a/f3111.html

8. Alan RP 2007. information technology intellectual property ethics; issues and analysis. Issue in Information system, 8(2).

9. WIPO . Intellectual property and bioethics-An overview.

10. Intellectual property rights -II. IPRs and Economic development.

11. Strong domestic IPRs may spur domestic innovative activity, and thus affect ... patented (from an ethical point of view - these ethical issues are ... www.ww.uni-magdeburg.de/bwl2/Lehre/WTO/WTO-L6 2004

12.Whyte wolf 2010. Is Intellectual Property Itself Unethical? http://www.iacis.org/iis/2007 iis/PDFs/Peslak.pdf 